\title{
Short-term environmental variability and phytoplankton abundance in a shallow tidal estuary. II. Spring and fall
}

\author{
W. Litaker ${ }^{*}$, C. S. Duke**, B. E. Kenney, J. Ramus \\ Marine Laboratory, Duke University, Beaufort, North Carolina 28516, USA
}

\begin{abstract}
Fixed-point sampling of a shallow tidal estuary was performed hourly for $14 \mathrm{~d}$ periods to characterize phytoplankton biomass variability at 2 to $96 \mathrm{~h}$ periodicities via spectral analysis. In all, 28 parameters were monitored, encompassing meteorology, hydrology, water chemistry and phytoplankton production physiology. The spring (May 1982) and fall (November 1982) periods of rapidly changing water temperatures are compared. In spring, the estuary was in transition from riverine to lagoonal condition. Temperatures rose steadily $\left(22\right.$ to $\left.28^{\circ} \mathrm{C}\right)$, salinities $(23$ to $35 \%)$ and chl a biomass $\left(22 \mu \mathrm{g} \mathrm{l}^{-1}\right)$ were high, and dissolved inorganic nitrogen (DIN) low $(0.13 \mu \mathrm{M})$. Growth-limiting $\mathrm{N}$ was supplied as $\mathrm{NH}_{4}{ }^{+}$by biological remineralization, rising $(0.2$ to $3.0 \mu \mathrm{M})$ on 11 of 14 nights, then declining each following day to below detection. Higher ebb-tide chl a biomass produced a tidal signal. Diel tidal height variations and daily wind stress changes accounted for about half the daily 2 -fold oscillation in chl $a$, the remainder was driven by daytime phytoplankton growth followed by nighttime grazing losses. In fall, the estuary was more riverine $(20$ to $32 \%)$ and temperatures variable $\left(12\right.$ to $\left.20^{\circ} \mathrm{C}\right)$. Chl a biomass was low $\left(4 \mu \mathrm{g} \mathrm{l}^{-1}\right)$ and DIN high $(2.0 \mu \mathrm{M})$. Chl a varied at the tidal and interday periods. Interday changes were correlated with water temperature changes, in turn coupled to the passage of atmospheric fronts at 3 to $4 \mathrm{~d}$ intervals. In both spring and fall periodic ecological processes operating on time scales equivalent to phytoplankton cell division times were found to be important in controlling chl a biomass changes.
\end{abstract}

\section{INTRODUCTION}

The role of short-term processes in phytoplankton ecology has traditionally received little attention (Harris 1980). Here, short-term processes are those occurring at time-scales approximating phytoplankton division times. An algal cell, for example, needs only a brief period of nutrient supply to satisfy its needs for cell division. Thus the temporal scale of nutrient availability is of particular interest. The temporal distribution of growth-rate limiting nutrient is controlled by a number of forcing properties peculiar to each body of

Present addresses:

- Program in Molecular Biology and Biotechnology, CB\# 7100, 402 Taylor Hall, University of North Carolina at Chapel Hill, Chapel Hill, North Carolina, 27599, USA

-Advanced Sciences, Inc., PO Box 475, Ross, Ohio 45061. USA water. Estuaries, where terrestrial runoff and oceanic waters mix, may be subject to periodic variability at temporal scales which approximate the division times of phytoplankton cells in natural marine waters on the order of a day (Goldman et al. 1979). As such, estuaries represent an appropriate system in which to observe the role of short-term variability in phytoplankton ecology. The goal is to match the time constants of the sampling protocol with forcing properties and phytoplankton processes at the 'phytoplankton scale'.

The PULSE project conducted high-frequency, comprehensive sampling in the Newport River estuary, a shallow, tide-flushed estuary in the Outer Banks region of North Carolina, USA. This southeastern coastalplain estuary has a surface area of $27 \mathrm{~km}^{2}$, a mean depth of $1 \mathrm{~m}$ at mean low water (MLW) and is surrounded by Spartina alterniflora marsh. Phytoplankton growth in the Newport River is nitrogen-limited, as demonstrated by nitrogen-addition experiments (Thayer 1974). Little 
dissolved inorganic nitrogen (DIN) is supplied by tidal incursions of shelf waters, therefore the primary source of DIN is river loading and in situ remineralization, both benthic and from the water column.

The estuary was monitored for 2 wk periods in February, May, August and November 1982, and February 1983 , to catch the winter low, the spring rise, the summer high, and the autumn decline in water temperature. Twenty-eight parameters were monitored on an hourly basis, $24 \mathrm{~h}$ per day, to describe the meteorology, hydrology, water chemistry and phytoplankton physiology. Details of the sampling regime and results of winter and summer studies are provided in Litaker et al. (1987).

In these studies it was assumed that estuarine processes vary in a statistically non-random fashion, i.e. the variability is harmonic. Further, it was assumed that phytoplankton respond quantitatively to variability if it is of the appropriate frequency. There are some obvious environmental oscillators with periodicities approximating the phytoplankton cell-division times of $1 \mathrm{~d}$, e.g. tides and the passage of the sun. Their detection through spectral analysis techniques (Lewis \& Platt 1982) was allowed to dominate the experimental design.

We report here selected data from the PULSE project contrasting the period of rising water temperatures (May 1982) with the period of falling water temperatures (November 1982, Fig. 1). These 2 periods represent intermediate conditions between the extremes of winter and summer.

\section{MATERIALS AND METHODS}

Variables were measured hourly $\left(24 \mathrm{~d}^{-1}\right)$ from 14 to 28 May (spring) and from 5 to 17 November 1982 (fall).

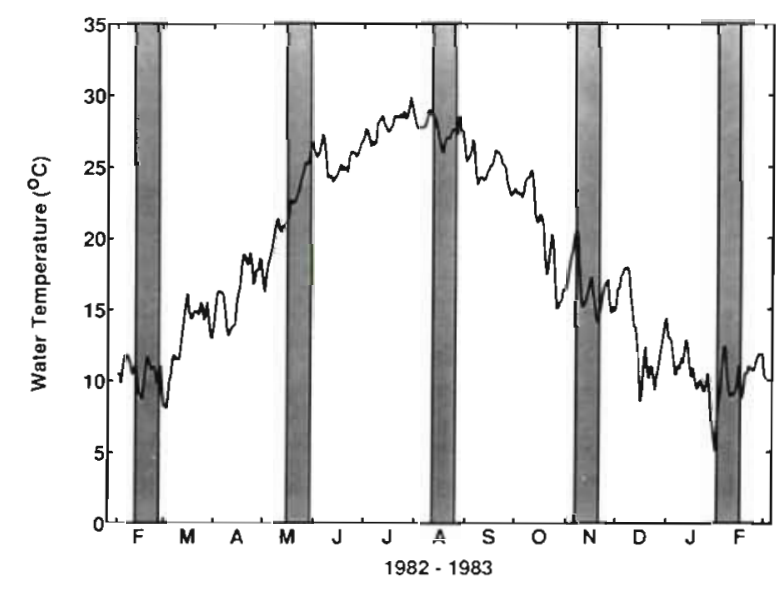

Fig. 1. Mean daily water temperature from February 1982 to February 1983 recorded at the Duke University Marine Laboratory dock. Shaded areas represent study periods. Data were kindly provided by Dr Bill Kirby-Smith
Salinity $(\%)$ as conductivity and water temperature were measured with an Industrial Instruments RS-5-2 salinometer. Dissolved oxygen (ppm) was measured using a YSI model $54 \mathrm{O}_{2}$ meter with Clark-type electrode. Percent oxygen saturation was calculated by dividing the dissolved $\mathrm{O}_{2}$ concentration by the saturation value determined by the sample temperature, salinity and barometric pressure conditions. Air temperature $\left({ }^{\circ} \mathrm{C}\right)$ and barometric pressure readings ( $\mathrm{mm} \mathrm{Hg}$ ) were obtained from the hourly recordings at the Cherry Point Marine Air Station $10 \mathrm{~km}$ NW of the sampling site. Rainfall $\left(\mathrm{mm} \mathrm{h}^{-1}\right)$ was measured with a calibrated rain gauge. Photosynthetically active radiation (PAR, $\mu$ Einstein $\mathrm{m}^{-2} \mathrm{~s}^{-1}$ ) was determined with a LiCor $192 \mathrm{~S}$ sensor attached to a recording integrator. Secchi depth $\left(Z_{\mathrm{SD}}\right)$ was measured using a $0.3 \mathrm{~m}$ Secchi disk attached to a calibrated pole. Attenuation coefficients $(k)$ were calculated from the $Z_{\mathrm{SD}}$ and the relationship $k=1.35 / Z_{\mathrm{SD}}$, determined empirically from simultaneous $Z_{\mathrm{SD}}$ and light attenuation measurements. Average light levels in the water column were calculated by the method of Riley (1957). Wind speed $\left(\mathrm{m} \mathrm{s}^{-1}\right)$ was measured with an anemometer and wind stress (dyne $\mathrm{cm}^{-2}$ ) estimated by $0.02 \times$ (wind speed) ${ }^{2}$ (Krauss 1978). Turbidity, as NTU, was measured with a Turner Designs 40 nephelometer. Residual nitrate $\left(\mathrm{NO}_{3}^{-}\right)$, nitrite $\left(\mathrm{NO}_{2}{ }^{-}\right)$and phosphate $\left(\mathrm{PO}_{4}{ }^{-3}\right)$ concentrations $(\mu \mathrm{M})$ were determined with a Technicon II Autoanalyzer system from filtered (Gelman A-E glass fiber) and frozen mid-water samples. Residual ammonium $\left(\mathrm{NH}_{4}{ }^{+}\right)$was determined in real time by the phenol hypochlorite method of Koroleff (1970). Chl a ( $\mu \mathrm{g} \mathrm{I}^{-1}$ ) was determined by fluorometric analysis (Turner Designs III fluorometer) of particulate material collected by gentle suction onto glass-fiber filters (Gelman A-E) and extracted into $90 \%$ acetone. Phaeopigments were determined by acidification of the acetone extract.

Power spectra of the primary data sets were obtained by a Fourier transform of the autocovariance function using a Parzen smooth and 48 lags. This analysis partitions total variance into equally spaced frequencies from 0 to 0.5 , revealing any dominant periodicities (Platt \& Denman 1975). Spectra were normalized to the total variance for comparative purposes. The spectral analysis program was written in BASIC and was based on algorithms presented in Otnes \& Enochson (1972), Dixon (1976; BMDO2T), and Chatfield (1980). The time series in this study, all of which were nonstationary, were analyzed without prewhitening in order to search for dominant harmonics. This lack of prewhitening causes an increased emphasis in amount of variation at low frequencies in time series with a general trend in the mean. As a check, first differencing was used to prewhiten all the data sets and make 
them more stationary prior to spectral analysis. The same significant peaks were found in both the transformed and untransformed data sets, though the relative magnitude of the peaks differed.

The correlation between data sets at various frequencies was estimated using cross-spectral analysis (Dixon 1976; BMDO2T). Coherence squared ( $\mathrm{Coh}^{2}$ ) estimates obtained by this technique may be considered frequency-based $r^{2}$ between 2 data sets (Harris 1983). Significant levels for $\operatorname{coh}^{2}$ were calculated by the method of Thompson (1979). Cross-spectral analysis also gives phase estimates between data sets at each of the discrete frequencies. The data were first differenced to make them more stationary and to reduce spurious cross-correlations resulting from high autocorrelations within individual series (Gottman 1981). Once the significant cross-correlations were identified, the 2 series were further aligned to prevent bias due to rapid phase changes (Chatfield 1980). First differencing and alignment increased significance relative to untransformed cross-correlations. However, the cross-correlations were also significant before data transformation, even at the higher frequencies.

The stepwise multiple regression analyses used a program based on the BMD algorithm O2R (Dixon 1976). Unless otherwise stated, $n=336$ and $p<0.001$.

\section{RESULTS}

\section{May 1982}

Tidal advection past a fixed sampling site controlled the portion of estuary sampled. Greater semi-diurnal salinity changes were therefore coincident with spring tides midway through the study (Fig. 2). Interday changes in mean salinity were also influenced by variations in freshwater input following a large rainfall event that occurred prior to the study period and to a minor extent after rainfall on 24 May.

Air temperatures oscillated between 7 to $14^{\circ} \mathrm{C}$ over the day, whereas water temperatures varied 2 to $3^{\circ} \mathrm{C}$. Water temperatures varied primarily at the interday periods and followed the interday trend in air temperature (Figs. 2 \& 3). Shallower portions of the estuary experienced greater diurnal heat gain, hence the lower salinity ebb-tide water was warmer than the higher salinity flood-tide water. This differential heating was apparent at the $12 \mathrm{~h}$ period (1) as a significant but minor tidal peak in the water temperature spectra (Fig. 3) and (2) as a significant negative crosscorrelation between water temperature and both salinity and water depth (Table 1).

Cross-correlation analysis also showed a weakly significant relationship between salinity and tempera- ture at the $24 \mathrm{~h}$ period. This variation in salinity and temperature was caused by unrelated mechanisms. In the case of salinity, the variation was due to minor harmonics in the diurnal tidal pattern, whereas temperature changes were due to diel heating and cooling of the entire estuary. Significant autocorrelation induced cross-correlations were therefore not eliminated in this instance, even with first differencing. The autocorrelation, however, was indicated by the inconsistent phase estimates between salinity and temperature at the 12 and $24 \mathrm{~h}$ periods (Table 1). Salinity and temperature were $180^{\circ}$ out of phase as would be expected at the $12 \mathrm{~h}$ period, but are approximately $270^{\circ}$ out of phase at the $24 \mathrm{~h}$ period. Phase estimates can therefore be useful in establishing when time series are merely correlated at a particular period, rather than being causally related.

Wind stress was generally highest in the late afternoon and lowest predawn, though there was considerable interday variation in the absolute magnitude of wind stress (Figs. 2, $3 \& 4$ ). At the diel period, wind stress was significantly cross-correlated with water temperature, turbidity and chl a (Table 1).

Turbidity was negatively correlated with water depth ( $\mathrm{r}=-0.795$; Fig. 2, Table 1). Consequently most of the variance was concentrated in the tidal period. There was also a significant, but reduced, peak at the $24 \mathrm{~h}$ period (Fig 3) which lags salinity and tide by approximately $15 \mathrm{~h}$ instead of the $12 \mathrm{~h}$ shift predicted on the basis of the tidal period phase relationship (Table 1). Cross-correlation and phase relationships between chl $a$, turbidity and salinity suggest changes in chl a biomass account for this $24 \mathrm{~h}$ periodicity in turbidity.

Both incident and water column irradiance were high throughout the sampling period and were not significantly altered by thunderstorms that occurred twice when 3 cold fronts moved through the area (Figs. 2 \& 3). Light attenuation as measured by Secchi disk was significantly correlated with turbidity $(\mathrm{r}=0.836, \mathrm{n}=210)$.

There was a regular association between the passage of low pressure systems and precipitation in both May and November (Fig. 2). Over a period of 3 to $4 \mathrm{~d}$, these warm and cold fronts caused 1 to $6^{\circ} \mathrm{C}$ changes in mean water temperature (Fig. 1). The magnitude of interday changes in temperature were greatest from late fall to early spring.

Active photosynthesis increased $\mathrm{O}_{2}$ saturation during the day (Kenney et al. 1988). However, heterotrophic activity kept daily dissolved oxygen concentrations below saturation for all but a few hours in the early afternoon (Figs. 2 \& 4). Ammonium was negatively correlated with $\mathrm{O}_{2}$ saturation ( $\left.\mathrm{r}=-0.523\right)$ suggesting that heterotrophic mineralization was a 

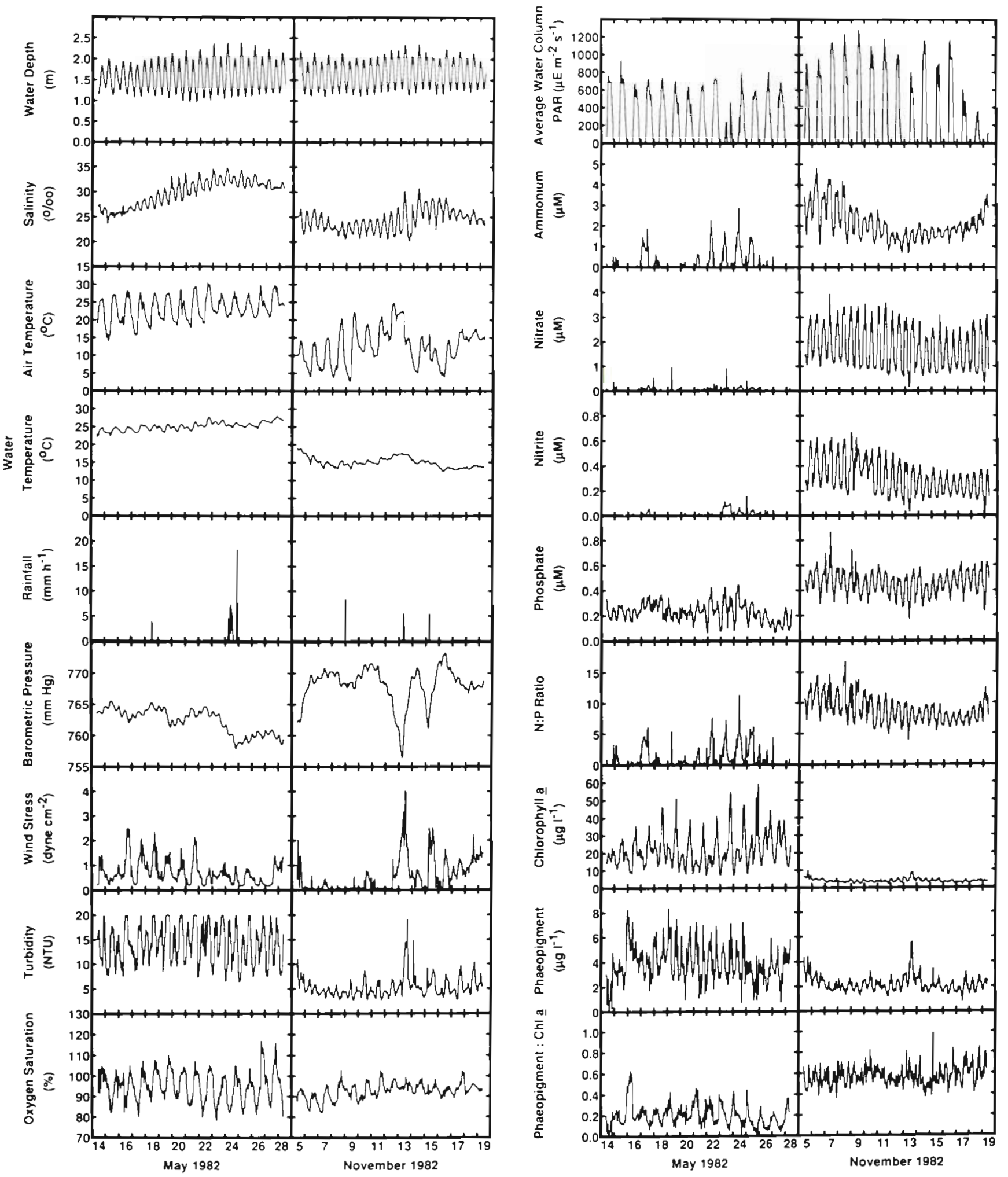

Fig. 2. The primary data sets for water depth, salinity, air temperature, water temperature, rainfall, barometric pressure, wind stress, turbidity, \% oxygen saturation, average water column PAR, $\mathrm{NH}_{4}{ }^{+}(\mu \mathrm{M}), \mathrm{NO}_{3}{ }^{-}, \mathrm{NO}_{2}{ }^{-}, \mathrm{PO}_{4}{ }^{-3}, \mathrm{~N}$ : P ratio, chl a, phaeopigment and phaeopigment: chl a ratio. The abscissa marks are at 00:00 h EST The low light conditions indicated midday on 23 May are a result of equipment failure. Light levels on 23 May were comparable to those on 22 May. The maximal turbidity standards available during the May study were 20 NTU. Turbidities increased slightly above this level for a few hours on certain days, indicated 

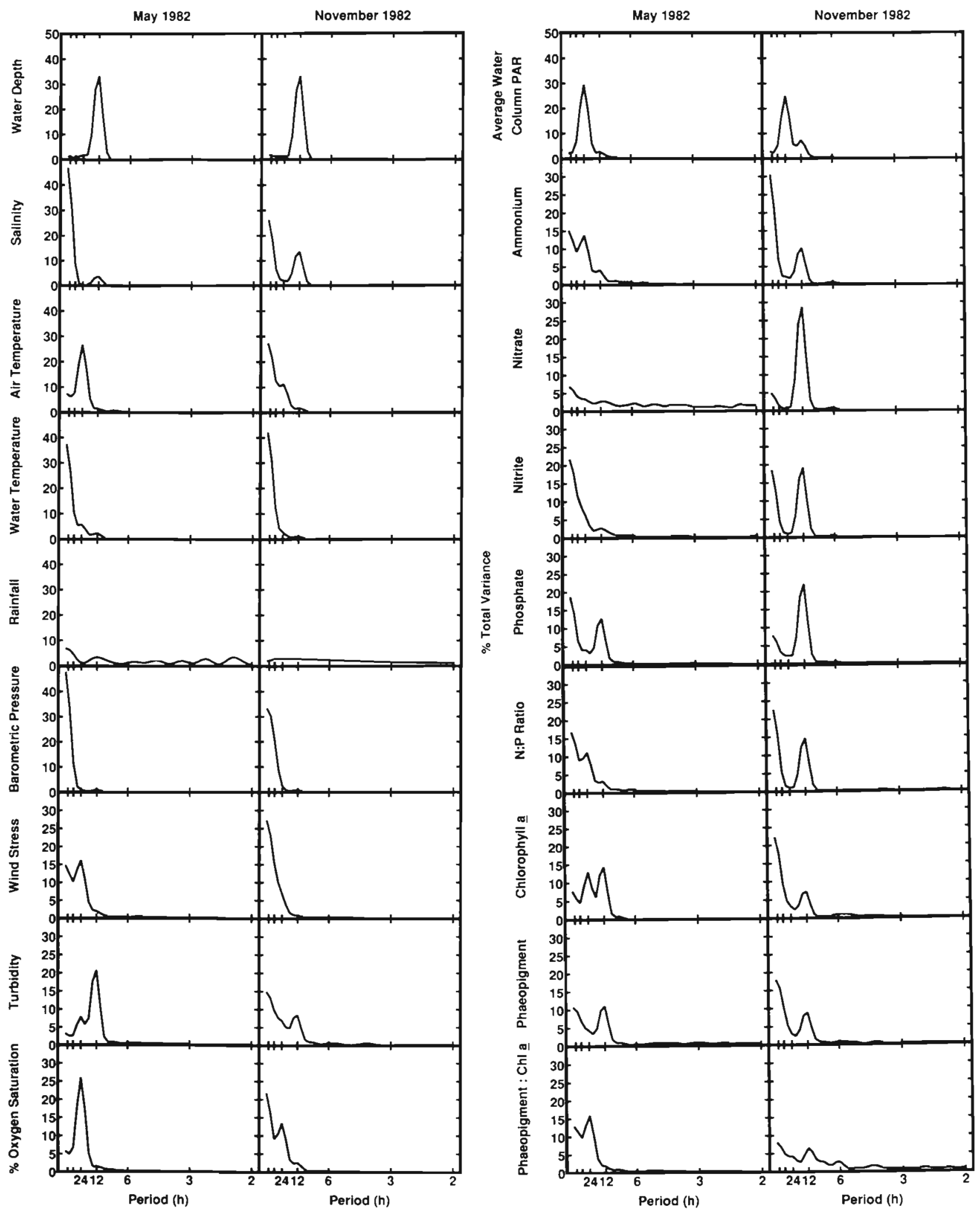

Fig. 3. Power spectra from the data sets presented in Fig. 2. The 2 abscissa marks to the left of the $24 \mathrm{~h}$ mark represent the $96 \mathrm{~h}$ and $7 \mathrm{~d}$ period estimates, respectively 


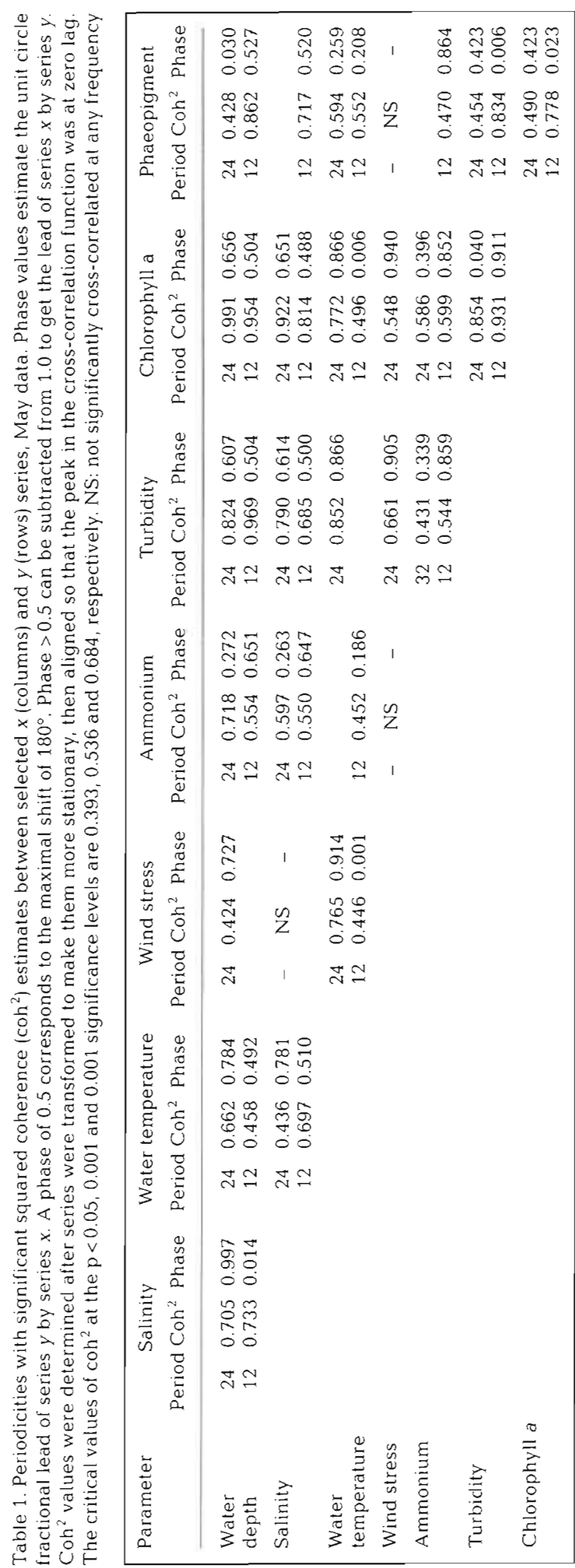

major source of $\mathrm{NH}_{4}{ }^{+}$. During the day residual $\mathrm{NH}_{4}{ }^{+}$ concentrations were below detection, but increased to between 0.1 and $3.0 \mu \mathrm{M}$ on 11 of the 14 nights during the study (Figs. $2 \& 4$ ). The most consistent nocturnal $\mathrm{NH}_{4}{ }^{+}$increases occurred when salinities exceeded $30 \%$ and temperatures were most similar to those in August when $\mathrm{NH}_{4}{ }^{+}$peaks occurred each night (Litaker et al. 1987).

The concentration of $\mathrm{NO}_{3}^{-}+\mathrm{NO}_{2}^{-}$in the Newport River was approximately $1 \mu \mathrm{M}$ during this period (Palumbo et al. 1988). However, most of the $\mathrm{NO}_{3}{ }^{-}$and $\mathrm{NO}_{2}{ }^{-}$was removed in the upper estuary before reaching the study site (Fig. 2) (Palumbo et al, 1988). Residual $\mathrm{NH}_{4}{ }^{+}$was consequently $6.5 \times$ more abundant than $\mathrm{NO}_{3}^{-}$at the study site. It should be emphasized, however, that this does not imply that $\mathrm{NO}_{3}^{-}$was unimportant. $\mathrm{NO}_{3}-\mathrm{N}$ supplied to the phytoplankton in the upper estuary by river input stimulates phytoplankton growth and becomes apparent at the study site as higher ebb-tide chl a biomass (Litaker et al. 1987, Rudek et al. 1991).

The few distinct $\mathrm{NO}_{3}{ }^{-}$peaks that did occur were not correlated with the $\mathrm{NH}_{4}^{+}$peaks (Fig. 2). Given that $\mathrm{NH}_{4}{ }^{+}$is seldom preferentially taken up when $\mathrm{NO}_{3}{ }^{-}$ concentrations are $<10 \mu \mathrm{M}$ (Kuenzler et al. 1979, Carpenter \& Dunham 1985), a significant positive correlation between $\mathrm{NO}_{3}{ }^{-}$and $\mathrm{NH}_{4}{ }^{+}$peaks would be predicted if river input was the major source of $\mathrm{NH}_{4}{ }^{+}$.

Phosphate was more closely associated with the tidal cycle $(\mathrm{r}=-0.618)$ than with salinity $(\mathrm{r}=-0.270$, $p<0.01$ ). Partial correlation analysis (Sokal \& Rohlf 1981) showed that when tide was held constant, salinity accounted for only $0.02 \%(r=-0.015, t=0.276, p=$ NS) of the $\mathrm{PO}_{4}^{-3}$ variance. When salinity was held constant, tide accounted for $33 \%(r=0.578, t=16.23)$ of the variance. This suggests residual $\mathrm{PO}_{4}{ }^{-3}$ was largely supplied by benthic and/or water column remineralization, rather than river input. The variance spectra shows a minor diel peak, in phase and significantly cross-correlated with $\mathrm{NH}_{4}^{+}$(Fig. 2 ; $\mathrm{coh}^{2}=0.752$ ).

The N:P ratio averaged 1.3 for the entire sampling period and was above 10 in only 1 of 336 samples (Fig. 2). These values are well below the Redfield ratio of 16 (Redfield et al. 1963), indicating the system was N-limited.

Chl $a$ variance was concentrated in the diel and tidal periods (Figs. $3 \& 4$ ). The tidal period variation was significantly cross-correlated and approximately $180^{\circ}$ out of phase with tide and salinity (Table 1). The higher biomass at low tide was likely a response to greater DIN in the upper estuary. Also, the middle portion of the estuary contains a frontal zone where dispersion rates are lower relative to the more river flushed upper estuary and tidally flushed lower estuary (Hyle 1976). $\mathrm{Chl}$ a biomass is generally higher in this region when 
Fig. 4. Mean hourly measurements $\pm 1 \mathrm{SD}$ for water depth, average water column PAR, \% oxygen saturation, water temperature, $\mathrm{NH}_{4}^{+}$ and $\mathrm{PO}_{4}^{-3}$ and $\mathrm{N}: \mathrm{P}$ ratio, wind stress, turbidity, chl a, phaeopigment and phaeopigment:chl a ratio. Solid bars at the top of the graphs indicate the dark period
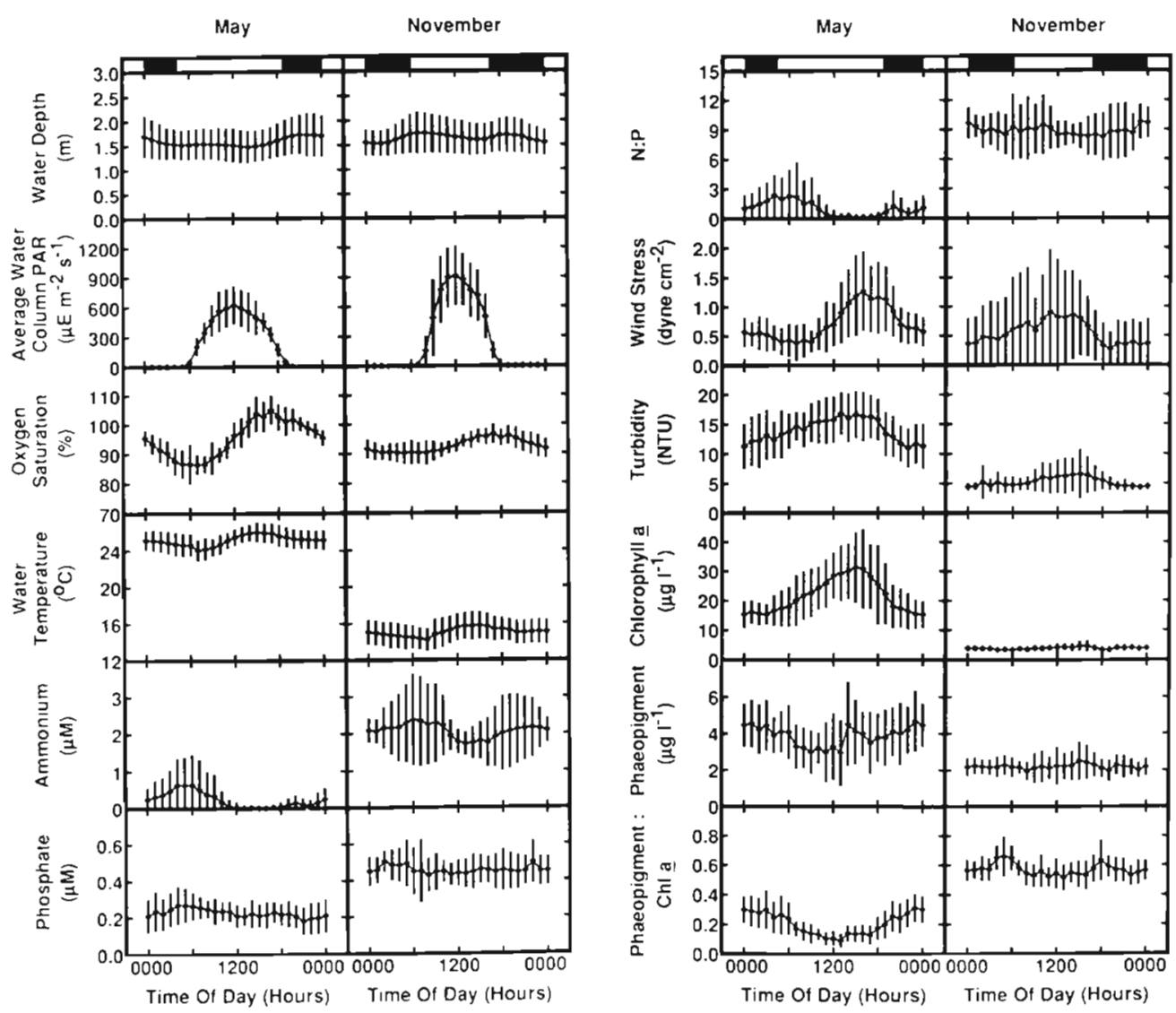

runoff is moderate to high and river flushing significant. This frontal zone was encountered on ebb tides during both the May and November studies.

The diel chl a variation was cross-correlated with tide, salinity and wind stress (Table 1). As with turbidity, chl a lags tide and salinity by $16 \mathrm{~h}$ instead of the $12 \mathrm{~h}$ predicted by the tidal period relationship. This suggests a third factor that was out of phase with the diel tidal variation. A likely candidate was wind stress, which was weakly cross-correlated and nearly in phase with chl a at the diel period (Table 1). This crosscorrelation suggests phytoplankton and particulate matter were suspended during the day when wind stress was high, then sank to the bottom at night as wind stress abated. To analyze the possible relationship between chl $a$ and wind stress, tidal height, and turbidity, the data were split. Average wind stress during the first $8 \mathrm{~d}$ was more than twice that of the last $6 \mathrm{~d}$ and varied more regularly throughout the day (Fig. 5). Approximately $36 \%$ of the variation in chl a was associated with the tide and $25 \%$ with wind stress during the first $8 \mathrm{~d}$ (Table 2). However, during the second $6 \mathrm{~d}$, when wind stress was $<1$ dyne $\mathrm{cm}^{-2}, 50 \%$ of the variation in chl a was associated with the tide and $<1 \%$ with wind stress. Greater diel chl a changes were also observed during the second $6 \mathrm{~d}$, again indicating wind suspension was secondary to tide or other factors in driving the diel chl a variation (Fig. 5).

The chl $a$ and wind stress data were further divided into 7 wind stress categories from 0 to 3 dyne $\mathrm{cm}^{-2}$, to determine if chl a was only suspended at higher wind speeds. No significant linear correlations between wind stress and chl a were found within any of the wind stress ranges. Similarly, no significant relationship was found when average wind stress and chl a for each wind stress range were compared.

The possibility that wind stress was resuspending $\mathrm{chl}$ a only at low tide was examined using the chl a versus wind stress regression coefficients for subsamples of the data falling into the following 4 categories: $\pm 1 \mathrm{SD}$ above or below mean tidal height either during the day or at night. Again no significant association between wind stress and chl a was found. Further evidence against wind suspension is presented in Stearns et al. (1987), where a diel chl a pattern persisted during the passage of tropical storm Dennis when nocturnal wind speeds were in excess of $23 \mathrm{~m} \mathrm{~s}^{-1}$. These observations are consistent with (1) wind stress accounting for only a minor portion of the diel change in chl a and (2) some other factor besides wind or diel variation in tidal height being responsible for half of the diel chl a change. 


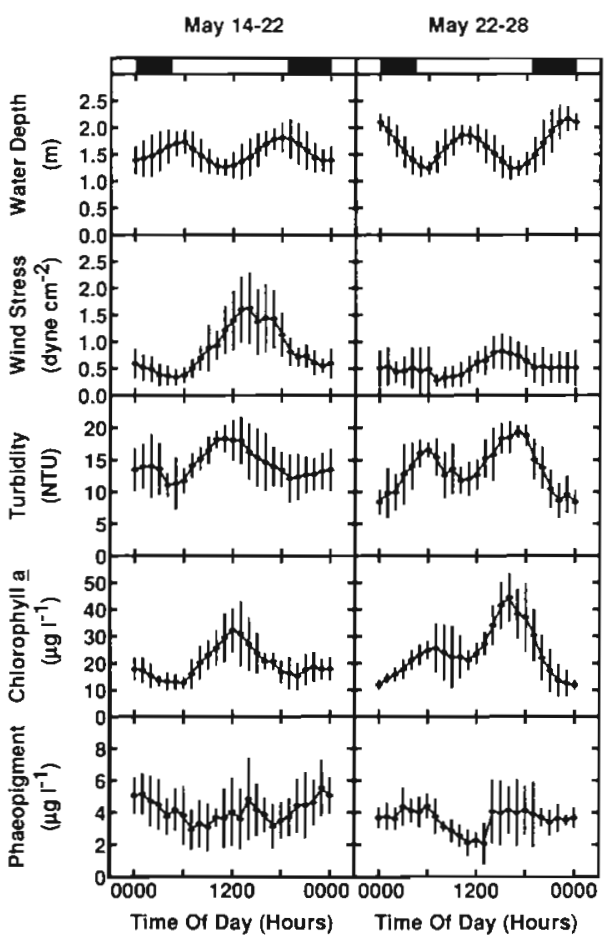

Fig. 5. Mean hourly measurement \pm 1 SD for wind stress, turbidity, chl a and phaeopigment for the first $8 \mathrm{~d}(\mathrm{n}=192)$ of the sampling period when wind stress was greater and showed a more regular diel rhythm and for the last $6 \mathrm{~d}(\mathrm{n}=144)$ when wind speeds were lower and more irregular

Phaeopigment varies throughout the study primarily at the tidal and interday periods (Figs. $2 \& 3$ ). The tidal variation was due to increased phaeopigment concentrations at ebb tide (Fig. 2). The interday variation in phaeopigment, however, was not significantly crosscorrelated with any of the other variables at the interday period. The phaeopigment: chl a ratio varied primarily at the diel period in response to the more intense changes in chl $a$.

\section{November 1982}

Water depth variations during the November study were similar to those in May (Fig. 2). However, higher Newport River flow rates caused approximately $5 \%$ lower salinities and correspondingly steeper salinity gradients over a tidal cycle. Interday variation in salinity was not significantly cross-correlated with tidal height. Part of the interday variation was instead attributable to changes in wind speed and direction. Wind speed increased and remained southerly between 11 and 12 November, and water accumulated in the estuary (Fig. 2). Early on the morning of 13 November, the wind shifted to the north and intensified. Water was then driven out of the estuary, and an unusually low tide occurred. Salinities increased from 11 to 13 November and then decreased transiently after the wind direction shifted. The wind shift was also accompanied by the greatest current speeds ( $>60 \mathrm{~cm} \mathrm{~s}^{-1}$ ) as water rushed out of the estuary.

Air temperatures varied primarily from day to day with secondary variation over the light-dark cycle (Figs. 2 \& 3). Water temperatures followed the interday trend in air temperature.

The 3 rainfall events that occurred were of similar magnitude and did not greatly alter the prevailing horizontal salinity structure of the estuary (Fig. 2). As

Table 2. Pearson product-moment correlation coefficients between water depth, salinity, wind stress, turbidity, chl $a$ and phaeopigment for the first $8 \mathrm{~d}$ of the study, 08:00 h 14 May to 08:00 h 22 May ( $\mathrm{n}=192$ ), and for the $6 \mathrm{~d}$ period from 09:00 h 22 May to $08: 00$ h 28 May $(n=144)$

\begin{tabular}{|c|c|c|c|c|c|c|}
\hline Рагameter & $\begin{array}{l}\text { Water } \\
\text { depth }\end{array}$ & Salinity & $\begin{array}{l}\text { Wind } \\
\text { stress }\end{array}$ & Turbidity & $\mathrm{Chl} \mathrm{a}$ & Phaeopigment \\
\hline \multicolumn{7}{|l|}{14 to 22 May } \\
\hline Water depth & 1.000 & 0.368 & -0.058 & -0.732 & -0.639 & -0.481 \\
\hline Salinity & & 1.000 & -0.051 & -0.086 & -0.320 & -0.150 \\
\hline Wind stress & & & 1.000 & 0.402 & 0.519 & 0.071 \\
\hline Turbidity & & & & 1.000 & 0.744 & 0.401 \\
\hline Chl a & & & & & 1.000 & 0.322 \\
\hline Phaeopigment & & & & & & 1.000 \\
\hline \multicolumn{7}{|l|}{22 to 28 May } \\
\hline Water depth & 1.000 & 0.768 & -0.039 & -0.859 & -0.733 & -0.417 \\
\hline Salinity & & 1.000 & -0.164 & -0.663 & -0.674 & -0.277 \\
\hline Wind stress & & & 1.000 & 0.139 & 0.143 & 0.161 \\
\hline Turbidity & & & & 1.000 & 0.788 & 0.409 \\
\hline $\mathrm{Chl} \mathrm{a}$ & & & & & 1.000 & 0.187 \\
\hline Phaeopigment & & & & & & 1.000 \\
\hline
\end{tabular}


in May, these events were associated with the passage of low pressure systems.

Wind stress varied primarily on an interday basis, and unlike May, showed only a minor diel variation (Figs. 2, $3 \& 4$ ). Wind stresses in excess of 3.5 dyne $\mathrm{cm}^{-2}$ were associated with the shift in wind direction and increase in turbidity and chl $a$ on 13 November (Fig. 2). Slightly less intense wind stress on 15 November did not trigger a similar increase in chl a or turbidity, suggesting that the chl a increase on 13 November was due primarily to increased flow, and only secondarily to high wind stress.

Variance in turbidity was concentrated in the $12 \mathrm{~h}$ and interday periods. The $12 \mathrm{~h}$ period variance was caused by the higher turbidities at ebb tide and the interday variation was most significantly crosscorrelated with chl $a$ and phaeopigment (Table 3).

Percent oxygen saturation varied primarily at the interday and diel periods. As in May, $\mathrm{O}_{2}$ was below saturation most of the time.

Incident irradiances were high except from 17 to 19 November when cloudy conditions prevailed. However, turbidities were sufficiently low during this brief period that average water column irradiances were above those needed to saturate photosynthesis for several hours each day (Figs. $2 \& 4$ ) (Kenney et al. 1988).

Residual $\mathrm{NH}_{4}{ }^{+}$concentrations varied primarily at the $12 \mathrm{~h}$ and interday periods (Figs. 2, $3 \& 4$ ). The $12 \mathrm{~h}$ variation was due to higher $\mathrm{NH}_{4}{ }^{+}$in the low tide, low salinity water. River inputs account for much of the higher $\mathrm{NH}_{4}{ }^{+}$(Litaker 1986). However, the stronger correlation of $\mathrm{NH}_{4}{ }^{+}$with tidal height than salinity indicates remineralization was an equally important source of $\mathrm{NH}_{4}{ }^{+}$(Table 3). Superimposed on the tidal variation was the larger interday variance in $\mathrm{NH}_{4}^{+}$ which was cross-correlated with $\mathrm{O}_{2}$ saturation $\left(\mathrm{coh}^{2}=\right.$ 0.769 , phase $=0.500 ; r=-0.532$ ) and not salinity. The correlation with $\mathrm{O}_{2}$ is consistent with the balance between biological remineralization and uptake largely controlling $\mathrm{NH}_{4}{ }^{+}$concentrations at the study site. Residual $\mathrm{NH}_{4}{ }^{+}$concentrations were 2 to 3 times higher than in May (Fig. 2).

Nitrate was strongly correlated with salinity, indicating river inputs were largely diluted downstream (Figs. 2, $3 \& 4$ ). Under the prevailing conditions where $\mathrm{NH}_{4}{ }^{+}>1 \mu \mathrm{m}, \mathrm{NH}_{4}{ }^{+}$is preferentially taken up over $\mathrm{NO}_{3}{ }^{-}$ (Kuenzler et al. 1979). Thus, in the absence of regeneration, the relative proportion of $\mathrm{NH}_{4}{ }^{+}$in the DIN pool would drop. Instead $\mathrm{NH}_{4}{ }^{+}$constituted an increasing portion of the $\mathrm{N}$ pool in flood tide water, as evidenced by the correlation of $\mathrm{NH}_{4}{ }^{+} /\left(\mathrm{NH}_{4}{ }^{+}+\mathrm{NO}_{2}{ }^{-}+\mathrm{NO}_{3}{ }^{-}\right)$with tide $(r=0.610)$ and salinity $(r=0.520)$. These data further support significant remineralization of $\mathrm{NH}_{4}{ }^{+}$ within the estuary.

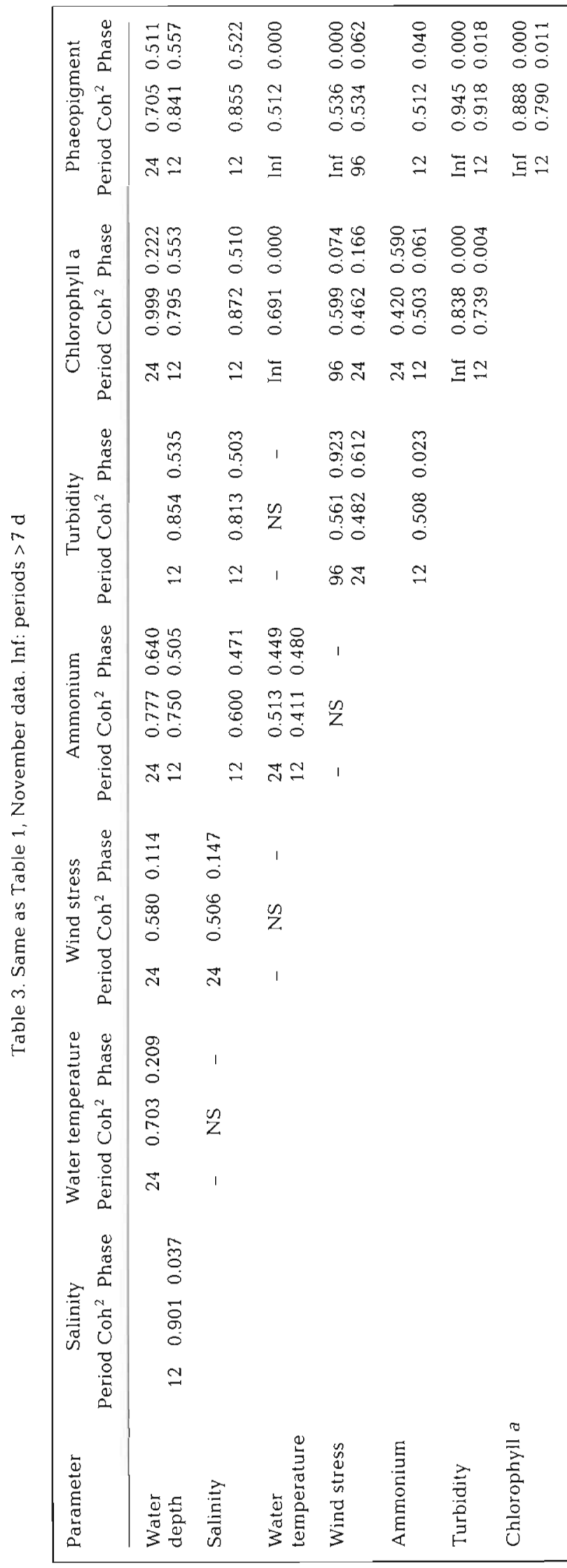


Residual $\mathrm{NO}_{2}^{-}$concentrations were much lower than $\mathrm{NO}_{3}$, but exhibited a similar variance pattern (Figs. 2 , $3 \& 4)$.

Nutrient concentrations were measured in the upper portion of the Newport River estuary at 08:00 h on 12 November. The salinity was $15 \%$ and concentrations of $\mathrm{NH}_{4}{ }^{+}, \mathrm{NO}_{3}^{-}, \mathrm{NO}_{2}^{-}$and $\mathrm{PO}_{4}^{-3}$ were $1.4,3.6,0.63$ and $0.65 \mu \mathrm{M}$, respectively. The $\mathrm{NH}_{4}{ }^{+} /\left(\mathrm{NH}_{4}{ }^{+}+\mathrm{NO}_{2}{ }^{-}+\mathrm{NO}_{3}{ }^{-}\right)$ ratio was 0.25 and the $\mathrm{N}$ : P ratio was 8.6 , showing that relative to the mid-estuarine study site, the upper estuary was less $\mathrm{N}$-limited and that the total DIN pool contained proportionately less $\mathrm{NH}_{4}{ }^{+}$(Fig. 2).

Residual $\mathrm{PO}_{4}^{-3}$ was more strongly cross-correlated with tide $\left(\mathrm{Coh}^{2}=0.937\right)$ than salinity $\left(\mathrm{Coh}^{2}=0.823\right)$ indicating remineralization and uptake slightly modified $\mathrm{PO}_{4}^{-3}$ levels being supplied by the river.

The $\mathrm{N}: \mathrm{P}$ atom ratio varied at the interday and tidal period (Figs, $2 \& 3$ ). The interday variation was attributable to the interday variation in $\mathrm{NH}_{4}{ }^{+}$, whereas the tidal component in $\mathrm{NH}_{4}{ }^{+}, \mathrm{NO}_{2}{ }^{-}$, and $\mathrm{NO}_{3}^{-}$all contributed to the tidal variation in the ratio. A plot of $\mathrm{N}: \mathrm{P}$ ratio versus salinity suggests that the estuary becomes progressively more $\mathrm{N}$-limited downstream of the Newport River (Fig. 6).

Chl a varied at the interday and tidal periods (Figs. 2 $\& 3)$. The interday variation was cross-correlated with water temperature at the interday periods $(r=0.569$; Table 3), but not with salinity. At the $12 \mathrm{~h}$ period, chl a was cross-correlated with both tide and salinity, but not water temperature (Table 3). Unlike May, there was no indication of a diel rhythm in chl a.

Phaeopigment variance was similarly concentrated in the interday and tidal periods (Figs. 2 \& 3). The interday variance was significantly cross-correlated with temperature, but not with tide or salinity (Table 3). Like chl a, phaeopigment was significantly crosscorrelated with tide and salinity at the $12 \mathrm{~h}$ period, but not with temperature. The tidal variation was due to

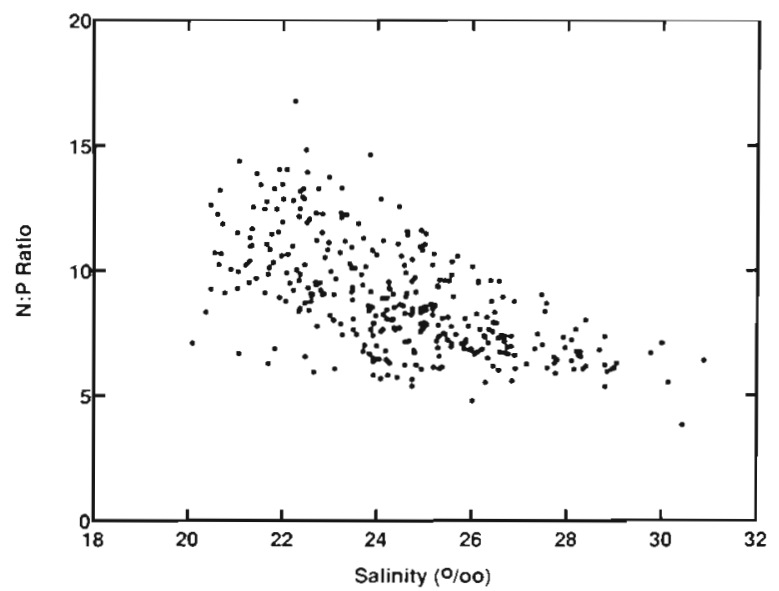

Fig. 6. N: P ratio versus salinity during the November 1982 study higher phaeopigment concentrations at ebb tide. The interday phaeopigment variation tracked mean air temperature as was the case for chl a. The phaeopigment: chl a ratio varied primarily at the interday and $12 \mathrm{~h}$ periods with a minor peak at $24 \mathrm{~h}$ (Figs. 2 $\& 3)$, reflecting the interday and tidal components of both chl $a$ and phaeopigment. Phaeopigment:chl a ratios were 2 to 3 times higher in November than in May.

\section{DISCUSSION}

The Newport River Estuary is riverine in winter and lagoonal in summer (Litaker et al. 1987). In winter, DIN loading (as $\mathrm{NO}_{3}^{-}$and $\mathrm{NH}_{4}{ }^{+}$) is proportional to river flow. Chl a biomass increases in the mid-estuary as lower salinity, DIN-enriched water moves downstream following runoff events. The dominant period of variation in chl $a$ is around $4 \mathrm{~d}$, corresponding to the passage of atmospheric fronts. There was also a pronounced tidal variation, with higher biomass in the lower salinity, higher DIN water mass (Litaker et al. 1987). Similar chl a increases in response to river DIN inputs have been observed in the nearby Neuse River estuary (Rudek et al. 1991).

In summer, the estuary becomes lagoonal with little runoff and nutrient input. Variation in growth regulating DIN and chl a biomass occurs primarily at the diel period, driven by biological processes coupled to the light-dark cycle. Remineralized $\mathrm{NH}_{4}{ }^{+}$accumulates at night, then declines during the day as light-dependent uptake exceeds remineralization (Litaker et al. 1988). In response to the $\mathrm{NH}_{4}{ }^{+}$uptake, chl a biomass approximately doubles from dawn to late afternoon as phytoplankton growth exceeds grazing losses. Beginning in late afternoon the balance shifts, grazing losses exceed growth, and chl a declines to predawn levels (Litaker et al. 1988).

Changes in chl a biomass keyed to atmospheric frontal systems in winter to the light: dark cycle in summer are largely governed by temperature. Summertime water temperatures often equal or exceed $25^{\circ} \mathrm{C}$, permitting maximal growth rates of 3 to 5 doublings per day (Furnas 1982, Honjo \& Tabata 1985). Phytoplankton are therefore capable of responding to intraday environmental variations. Wintertime water temperatures, in contrast, are generally below $12^{\circ} \mathrm{C}$, limiting maximum phytoplankton growth rate $\left(\mu_{\max }\right)$ to less than 1.1 doublings per day (Côté \& Platt 1983). Wintertime populations therefore have only limited ability to alter their growth rates rapidly in response to intraday environmental variation. Instead, intraday variations are integrated and translated into growth rates changes at periods equal to or greater than $1 \mathrm{~d}$ 
(Harris 1980). Thus temperature determines the potential for chl a biomass to fluctuate over the course of a day by controlling $\mu_{\max }$.

In the Newport River estuary, mean daily water temperatures, and hence potential productivity and phytoplankton growth rates, are not distributed evenly throughout the year (Kenney et al. 1988). Each spring and fall water temperatures change, with the estuary abruptly shifting state between winter and summer conditions. Consequently, there are relatively few days in a year when water temperatures fall between 18 and $22^{\circ} \mathrm{C}$ (Kenney et al. 1988). These transitions generally occur in May and November (Fig. 1). The estuary is therefore warmer $\left(>22^{\circ} \mathrm{C}\right)$ from late May to mid October and cooler $\left(<18^{\circ} \mathrm{C}\right)$ from mid November to early May.

The goal of the May and November studies was to determine if chl a biomass responded to environmental variations on the order of phytoplankton division times during the spring-fall temperature transitions. The May study actually sampled the 2 wk period when water temperatures had just passed the 18 to $22^{\circ} \mathrm{C}$ transition (Fig. 1). During this study, water temperatures rose steadily from 22 to $28^{\circ} \mathrm{C}$ (Fig. 2). In contrast, water temperatures during the November study declined from 20 to $12.5^{\circ} \mathrm{C}$ over the first $3 \mathrm{~d}$, then fluctuated between 12 and $17^{\circ} \mathrm{C}$ thereafter. Hence, November more fully represented the transition through the 18 to $22^{\circ} \mathrm{C}$ range. The temperature differences between May and November influenced river flow, as evapotranspiration rates are proportional to temperature (Thornthwaite \& Mather 1955, 1957). Thus the average salinity regime in the middle portion of the estuary was about 5\% higher in May than November (Fig. 2).

Chl a biomass was also significantly different between the 2 studies, varying between 8 and $60 \mu \mathrm{gl}^{-1}$ in May and 2 and $10 \mu \mathrm{g} \mathrm{l}^{-1}$ in November (Fig. 2). These differences in temperature and chl a biomass alter the patterns and magnitude of DIN variation.

In May, $\mathrm{NH}_{4}{ }^{+}$was the predominant $\mathrm{N}$ form and variation was concentrated in the diel and interday periods (Fig. 3). Nocturnal $\mathrm{NH}_{4}{ }^{+}$concentrations generally rose to between 0.5 and $3 \mu \mathrm{M}$, then declined below detection levels during the day as light-dependent uptake exceeded remineralization. This pattern is most consistent when salinities increased from $30 \%$ to the 34 to $35 \%$ salinity range present in August (Fig. 2) (Litaker et al. 1987). The interday variation in the magnitude of the nocturnal $\mathrm{NH}_{4}{ }^{+}$increase was likely due to differences in chl a specific $\mathrm{NH}_{4}{ }^{+}$uptake rates. During the last $3 \mathrm{~d}$ of the study, maximal $\mathrm{NH}_{4}{ }^{+}$uptake rates were measured at 3 to $5 \mathrm{~h}$ intervals and found to be inversely correlated with $\mathrm{NH}_{4}{ }^{+}$concentration (Litaker 1986). This correlation suggests that nocturnal uptake rates are generally less than the rates of $\mathrm{NH}_{4}{ }^{+}$supply thereby allowing $\mathrm{NH}_{4}{ }^{+}$accumulation in the water column. On certain nights, however, uptake rates remained high enough to keep residual $\mathrm{NH}_{4}^{+}$levels below detection. $\mathrm{NH}_{4}{ }^{+}$accumulation during most nights demonstrates that the diel $\mathrm{NH}_{4}{ }^{+}$variation characteristic of August establishes rapidly after the 18 to $22^{\circ} \mathrm{C}$ transition (Litaker et al. 1987). Thus, in both May and August, diel $\mathrm{NH}_{4}{ }^{+}$variation was driven by remineralization and uptake processes associated with the light: dark cycle.

Biological remineralization as the primary source of $\mathrm{NH}_{4}{ }^{+}$within the estuary is supported by the significant inverse association between oxygen saturation and $\mathrm{NH}_{4}{ }^{+}$. Such an association is expected if catabolic processes lead to $\mathrm{NH}_{4}{ }^{+}$production (Nixon 1981). Additionally, highest nocturnal $\mathrm{NH}_{4}{ }^{+}$concentrations at salinities greater than $30 \%$ argues against significant river inputs of $\mathrm{NH}_{4}{ }^{+}$reaching the study site (Fig. 2, Table 1).

The low biomass of November only partially removed DIN inputs from the river. $\mathrm{NO}_{3}{ }^{-}$and $\mathrm{NO}_{2}^{-}$ supplied by the river were largely diluted down the estuary without significant uptake (Fig. 3, Table 3). The $>1 \mu \mathrm{M}$ residual $\mathrm{NH}_{4}{ }^{+}$concentrations would account for $\mathrm{NO}_{3}^{-}$uptake suppression. Kuenzler et al. (1979) found that $\mathrm{NH}_{4}{ }^{+}>1 \mu \mathrm{M}$ reduced $\mathrm{NO}_{3}{ }^{-}$uptake in the nearby Pamlico River estuary, whereas $\mathrm{NH}_{4}{ }^{+}>$ $3 \mu \mathrm{M}$ totally suppressed uptake. Dortch et al. (1991) similarly found that as ammonium concentrations were increased from 1 to $5 \mu \mathrm{M}$, nitrate uptake was reduced to very low, but still detectable, levels.

In contrast to $\mathrm{NO}_{3}{ }^{-}, \mathrm{NH}_{4}{ }^{+}$was supplied by both river input and biological remineralization in November. This remineralization process was evident in the significant relationship between tide and the relative contribution of $\mathrm{NH}_{4}^{+}$to the total DIN pool. $\mathrm{NH}_{4}{ }^{+}$ initially accounts for 20 to $50 \%$ of total DIN at ebb tides and 50 to $80 \%$ at flood tides. Remineralization evident in the summer months therefore continues to some degree after the sudden decline in temperature. Kuenzler et al. (1984) similarly found benthic $\mathrm{NH}_{4}{ }^{+}$remineralization continuing into the fall at a reduced rate relative to summer, but at considerably higher rates than for corresponding springtime temperatures.

Ammonium, in contrast to $\mathrm{NO}_{3}^{-}$, varied more strongly at the interday periods than at the tidal period (Fig. 3). This interday variation was inversely associated with $\mathrm{O}_{2}$ saturation, suggesting differences in phytoplankton uptake and remineralization contributed to the interday $\mathrm{NH}_{4}{ }^{+}$variation (Fig. 3, Table 3).

The $\mathrm{N}$ : P ratio $<16$ during both spring and fall indicates $\mathrm{N}$ - rather than P-limitation. The degree of $\mathrm{N}$ limitation also varied spatially during both studies, with the estuary becoming progressively more $\mathrm{N}$ regulated downstream from the Newport River (Fig. 6). 
Though $\mathrm{PO}_{4}^{-3}$ was not limiting, ambient concentrations were consistently more closely associated with tidal height than with salinity in both May and November (Tables 1 \& 2). This implies regeneration and uptake within the estuary significantly modified residual $\mathrm{PO}_{4}^{-3}$ concentrations during both periods

DIN inputs from the Newport River were similar in November 1982 and February 1983 (authors' unpubl. data), yet residual DIN was below detection limits in February (Litaker et al. 1987). Chl a levels in November were similar to the first portion of the February sampling period, thus uptake demand by a larger phytoplankton standing stock cannot account for low residual DIN in February compared to November (Fig. 2) (Litaker et al. 1987). The difference was likely due to temperature suppression of $\mathrm{N}$ remineralization during the coldest months of the year (Fisher et al. 1982). During this period, river input becomes the primary DIN source. In February, these DIN inputs were removed by phytoplankton in the upper estuary before reaching the study site. In November, however, $\mathrm{NH}_{4}{ }^{+}$remineralization met much of the phytoplankton $\mathrm{N}$-demand, and the $\mathrm{NO}_{3}{ }^{-}$and $\mathrm{NO}_{2}{ }^{-}$supplied by the river was present in the water column at the study site.

A difference in remineralization between November and February is also consistent with the community oxygen metabolism reported by us (Kenney et al. 1988). From May through November, the estuary was net heterotrophic, using more organic $\mathrm{C}$ and $\mathrm{O}_{2}$ than was produced by the photoautotrophs in the system. During this period, $\mathrm{O}_{2}$ saturation was below $100 \%$ for all but a few hours during each day, demonstrating high levels of respiration that would be associated with $\mathrm{NH}_{4}{ }^{+}$remineralization (Nixon 1981, Litaker et al. 1987). In contrast, the estuary was net autotrophic in February, producing excess organic $\mathrm{C}$ and $\mathrm{O}_{2}$ for export, internal consumption, or deposition to the sediments. During this period, the water column was supersaturated with oxygen, and residual $\mathrm{NH}_{4}{ }^{+}$concentrations below detection, consistent with comparatively lower respiratory activity and remineralization rates (Kenney et al. 1988).

The higher chl a biomass in May (avg. $22 \mu \mathrm{g} \mathrm{l}^{-1}$ ) versus November (avg. $4 \mu \mathrm{g} \mathrm{I}^{-1}$ ) was due to a diatom bloom characteristic of late spring. Light levels, nutrient supply and rising water temperatures are all conducive to this bloom (Litaker 1986). Interestingly, conditions seem equally conducive to phytoplankton growth in August, yet chl a levels were lower (avg. $16 \mu \mathrm{gl}^{-1}$ ). We speculate that some of the difference in chl a biomass between May and August were due to grazing differences. Zooplankton abundances are known to increase with increasing temperatures in the Newport River and other north temperate estuaries
(Heinle 1966, Sage \& Herman 1972, Bruno et al. 1980, Fleeger 1980, Turner 1982, Fulton 1984). Grazing rates are therefore elevated from May to October and highest in late summer.

The low chl a biomass in November is enigmatic. Water temperatures were low, but 5 to $10^{\circ} \mathrm{C}$ higher than in February when a Heterocapsa triquetra bloom began (Litaker et al. 1987). Hence absolute temperature per se is not regulating standing stock at this time. Residual DIN was more abundant than in any other season and light penetrated to the bottom with average light levels sufficient to saturate photosynthesis during most of the day (Litaker 1986). All conditions seem supportive of active phytoplankton growth, yet biomass is at an annual low. A similar annual chl a minimum in November was also observed in the Newport River estuary by Thayer (1971), suggesting this annual low has a recurrent cause. One possible explanation for the low chl a biomass would be high grazing losses relative to phytoplankton growth rates. This hypothesis is supported by the highest phaeopigment : chl a ratios of any season studied, indicating extensive microzooplankton grazing was occurring (Figs. $2 \& 4$ ) (Litaker et al. 1988).

The chl a variation pattern in May varied primarily at the tidal and diel periods and was intermediate between the patterns observed in August and February (Figs. $2 \& 3$ ) (Litaker et al. 1987). The tidal signal was attributed to higher chl a biomass at low tide in response to greater $N$ supply and lower dilution rates which favor higher biomass in lower salinity, ebb-tide water. The large shifts in biomass associated with runoff and increased DIN loading following rainfall events in February did not occur in May. Instead, the increased $\mathrm{N}$ remineralization and reduced river flow lessened the importance of interday DIN loading by the river in controlling chl a biomass. Consequently, the importance of atmospheric frontal systems in driving spatial and temporal variation was reduced compared to February.

Approximately $50 \%$ of the May diel chl a signal was attributable to diel variation in the tidal progression, and to a much lesser extent wind resuspension (Fig. 5). The remainder of the diel chl a change is likely due to the same biological processes responsible for the diel chl a cycle observed in August (Litaker et al. 1988). In that study, phytoplankton growth exceeded grazing losses and chl a levels increased about 2 -fold from early morning to late afternoon. Subsequently, late afternoon and evening grazing losses exceed growth and chl a levels declined. The diel change in turbidity associated with changes in chl a in May is consistent with a diel change in cell density in response to temporally varying growth and grazing rates seen in August. 
In November, chl a varied at the tidal and interday periods. Tidal variation, as in February and May, was due to the increased DIN and favorable dilution conditions associated with the ebb tide water mass. The interday variation was driven by the passage of atmospheric frontal systems as in February. However, the mechanisms by which the frontal systems affected chl a biomass differ. In February, atmospheric low pressure systems were generally associated with rainfall events that increase runoff and DIN loading to the estuary. This DIN input was then the primary $\mathrm{N}$ source for the estuary, and phytoplankton $\mathrm{N}$-demand was so high that residual DIN was below detection most of the time. Under these conditions chl a biomass increased in response to runoff. In November, however, chl a biomass was much lower. High residual DIN levels and the ratios of daytime to nighttime maximal uptake rates (Litaker 1986) indicate that autumnal phytoplankton biomass was the least $N$-regulated of any of the studies. Thus, instead of responding primarily to $\mathrm{N}$-loading, chl a biomass changes were associated with changes in water temperature. Interday changes in the growth rates of macroalgae from the Newport River estuary were also found to be predominantly dependent on daily temperature variations (Duke et al. 1989). These data suggest that temperature-induced increases or decreases in growth rate, relative to loss rates, determined interday variation in chl a biomass.

Hence, in the fall and winter, when phytoplankton growth rates are reduced, changes in temperature or DIN loading associated with the passage of atmospheric frontal systems were important drivers of chl a biomass. During the warmer periods, when water temperatures were above $22^{\circ} \mathrm{C}$ and phytoplankton growth rates high, biological processes associated with the light: dark cycle controlled changes in chl a biomass.

It is clear from this fixed-point study of estuarine variability that the high-frequency processes, i.e. processes with periods approximating division times, are important in phytoplankton ecology. Most of the variance in biologically important variables occurs at time scales of 12 to $96 \mathrm{~h}$ due to effects of physical events, including runoff, insolation, and temperature changes and to biological events associated with the light: dark cycle. Further, this study demonstrates that the coherent structure of estuarine dynamics is revealed when the time constants of sampling match those of physical, chemical and biological processes.

Acknowledgements. This work was supported by NSF grant OCE-81-13328 to J.R. Cherry Point Marine Air Station kindly provided the air temperature and barometric pressure data. Two anonymous reviewers provided constructive criticisms.

\section{LITERATURE CITED}

Bruno, S. F., Staker, R. D., Sharma, G. M. (1980). Dynamics of phytoplankton productivity in the Peconic Bay estuary, Long Island. Estuar. coast. Shelf Sci. 10: 247-263

Carpenter, E. J., Dunham, S. (1985). Nitrogenous nutrient uptake, primary production and species composition of phytoplankton in the Carmans River estuary, Long Island, New York. Limnol. Oceanogr. 30: 513-526

Chatfield, C. (1980). The analysis of time series: an introduction. Chapman and Hall, New York

Coté, B., Platt, T (1983). Day-to-day variation in the springsummer photosynthetic parameters of coastal marine phytoplankton. Limnol. Oceanogr. 28: 320-344

Dixon, W. J. (ed.) (1976). BMD Biomedical Computer Programs. University of California Press, Berkeley

Dortch, Q., Thompson, P. A., Harrison, P. J. (1991). Shortterm interaction between nitrate and ammonium uptake in Thalassiosira pseudonana: effect of preconditioning nitrogen source and growth rate. Mar. Biol. 110: 183-193

Duke, C. S., Litaker, W., Ramus, J. (1989). Effect of temperature on nitrogen-limited growth rate and chemical composition of Ulva curvata (Ulvales: Chlorophyta). Mar. Biol. 100: $143-150$

Fisher, T. R., Carlson, P. R., Barber, R. T. (1982). Sediment and nutrient regeneration in three North Carolina estuaries. Estuar. coast. Shelf Sci. 14: 101-116

Fleeger, J. W. (1980). Community structure of an estuarine meiobenthic copepod assemblage. Estuar. coast. Shelf Sci. 10: $107-118$

Fulton, R. S. III (1984). Distribution and community structure of estuarine copepods. Estuaries $7: 38-50$

Furnas, M. J (1982). Growth rates of summer nanoplankton $(<10 \mu \mathrm{M})$ populations in lower Narragansett Bay, Rhode Island, USA. Mar. Biol. 70: 105-115

Goldman, J. C., McCarthy, J. J., Peavey, D. G. (1979), Growth rate influence on the chemical composition of phytoplankton in oceanic waters. Nature 279: 210-215

Gottman, J. M. (1981). Time-series analysis: a comprehensive introduction for social scientists. Cambridge University Press, New York

Harris, G. P. (1980). Temporal and spatial scales in phytoplankton ecology. Mechanisms, methods and management. Can. J. Fish. Aquat. Sci. 37: 877-900

Harris, G. P. (1983). Mixed layer physics and phytoplankton populations: studies in equilibrium and non-equilibrium ecology. In: Round, F. E., Chapman, D. J. (eds.) Progress in phycological research, Vol. II. Elsevier Science Publishers B. V., Amsterdam, p. 1-52

Heinle, D. R. (1966). Production of a calanoid copepod, Acartia tonsa, in the Patuxent River estuary. Chesapeake Sci. $7: 59-74$

Honjo, T., Tabata, K. (1985). Growth dynamics of Olistodiscus luetus in outdoor tanks with flowing coastal seawater and in small vessels. Limnol. Oceanogr. 30: 653-664

Hyle, R. A. III (1976). Fishes of the Newport Piver estuary North Carolina, their composition, seasonality and community structure, 1970-1972. Ph.D. dissertation, University of North Carolina at Chapel Hill, Chapel Hill

Kenney, B. E., Litaker, W., Duke, C. S., Ramus, J. (1988). Community oxygen metabolism in a shallow tidal estuary. Estuar. coast. Shelf Sci. 27:33-43

Koroleff, I. (1970). Direct determination of ammonia in natural waters as indophenol blue. Information on techniques and methods for seawater analysis. Interlab. Rep. Cons. perm. int. Explor. Mer 3: 19-22 
Krauss, J. A. (1978). Introduction in physical oceanography. Prentice-Hall, Inc., Englewood Cliffs, NJ

Kuenzler, E. J., Stanley, D. W., Koenings, J. P. (1979). Nutrient kinetics of phytoplankton in the Pamlico River, North Carolina. Wat. Resour. Res. Rep. Inst. Univ. N. Carolina 139: $1-163$

Kuenzler, E. J., Albert, D. A., Allgood, G. S., Cabiniss, S. E., Wanat, C. G. (1984). Benthic nutrient cycling in the Pamlico River. Wat. Resour. Res. Rep. Inst. Univ. N. Carolina 215: 1-148

Lewis, M. L., Platt, T. (1982). Scales of variability in estuarine ecosystems. In: Kennedy, V. S. (ed.) Estuarine comparisons. Academic Press, New York, p. 3-51

Litaker, W. (1986). Dynamics of a well-mixed estuary. Ph.D. dissertation, Duke University

Litaker, W., Duke, C. S., Kenney, B. E., Ramus, J. (1987). Short-term environmental variability and phytoplankton abundances in a shallow tidal estuary. I. Winter and summer. Mar. Biol. 96: 115-121

Litaker, W., Duke, C. S., Kenney, B. E., Ramus, J. (1988). Diel chl $a$ and phaeopigment cycles in a shallow tidal estuary: potential role of microzooplankton grazing. Mar. Ecol. Prog. Ser. 47: 259-270

Nixon, S. W. (1981). Remineralization and nutrient cycling in coastal marine ecosystems. In: Neilson, B. J., Cronin, L. E. (eds.) Estuaries and nutrients. Humana Press, Clifton, NJ, p. 111-138

Otnes, R. K., Enochson, L. E. (1972). Digital time series analysis. John Wiley and Sons, New York

Palumbo, A. V., Pfaender, F. K., Paerl, H. W. (1988). Biodegradation of NTA and $\mathrm{m}$-Cresol in coastal environments. Environ. Toxicol. Chem. 7: 573-575

Platt, T., Denman, K. L. (1975). Spectral analysis in ecology. A. Rev. Ecol. Syst. 6: 189-210

Redfield, A. C., Ketchum, B. H., Richards, A. F. (1963). The

This article was submitted to the editor influence of organisms on the composition of seawater. In: Hill, M. M. (ed.) The sea, Vol. 2. Wiley-Interscience, London, p. 26-49

Riley, G. A. (1957). Phytoplankton of the north central Sargasso Sea. Limnol. Oceanogr. 2: 252-270

Rudek, J., Paerl, H. W., Mallin, M. A., Bates, P. W. (1991). Seasonal and hydrological control of phytoplankton limitation in the lower Neuse River Estuary, North Carolina. Mar. Ecol. Prog. Ser. 75: 133-142

Sage, L. E., Herman, S. S. (1972). Zooplankton of the Sandy Hook Bay area, N. J. Chesapeake Sci. 13: 29-39

Sokal, R. R., Rohlf, J. J. (1981). Biometry, 2nd edn. W. H. Freeman \& Co., New York

Stearns, D. E., Litaker, W., Rosenberg, G. (1987). Impacts of zooplankton grazing and excretion on short-interval fluctuations in chlorophyll $a$ and nitrogen concentrationsin a well-mixed estuary. Estuar. coast. Shelf Sci. 24: 305-325

Thayer, G. W. (1971). Phytoplankton production and the distribution of nutrients in a shallow unstratified estuarine system near Beaufort, N.C. Chesapeake Sci. 12: 240-253

Thayer, G. W. (1974). Identity and regulation of nutrients limiting phytoplankton production in the shallow estuaries near Beaufort, N.C. Oecologia 14: 75-92

Thompson, R. O. R. Y. (1979). Coherence significance levels. J. atmos. Sci. 36: 2020-2021

Thornthwaite, C. W., Mather, J. R. (1955). The water balance. Publications in Climatology, Vol. 8, No. 1. Centerton, NJ. p. 1-86

Thornthwaite, C. W., Mather, J. R. (1957). Instructions and tables for computing potential evapotranspiration and the water balance. Publications in Climatology, Vol. 10, No. 3. Centerton, NJ, p. 185-311

Turner, J. T. (1982). The annual cycle of zooplankton in a Long Island estuary. Estuaries 5: 261-274

Manuscript first received: September 7, 1989

Revised version accepted: February 3, 1993 